GENDER EQUALITY IN EDUCATION IN SRI LANKA

\author{
D P Withanage
}

D P S Chandrakumara
Sri Lanka Journal of

Economic Research

Volume 9(1) December 2021

SLJER 09.01.02: pp. 29-50

Sri Lanka Forum of

University Economists

DOI: http://doi.org/10.4038/sljer.v9i1.154

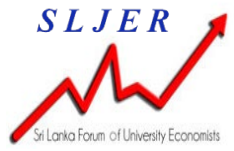

\begin{abstract}
Gender equality in education is an issue of global concern since it equalizes the formation of human capital and labour productivity between males and females. Hence, a gender equality analysis on education is essential to understand the situation and necessary policy interventions.

This paper aims to investigate how equally education and training are distributed between males and females in Sri Lanka. The study is mainly based on institutional data obtained from the Department of Education, University Grants Commission, and the Department of Census and Statistics. Descriptive statistics were used in the analysis of quantitative data. Results show that the country has achieved gender equality education in many aspects. However, it reveals that student enrolments in grade one in National in schools, engineering and technology study programmes in universities, vocational and non-formal training courses under technical, vocational, and non-formal education are male-biased. The enrolments in bio-science centred streams in universities, by contrast, are femalebiased.

The findings highlighted the need for policy intervention in minimizing gender inequality in Grade one admissions in National schools, enrolments in engineering, technology, and bio-science centred study programs, and vocational and non-formal training courses.
\end{abstract}

Keywords: Access to education, Gender equality, Vocational training, University admissions, Human capital

D P Withanage (Corresponding Author)

Department of Economics, University of Sri Jayewardenepura, Sri Lanka

Email:1withanage@sjp.ac.lk Tel: +94714551977

(iD https://orcid.org/0000-0002-8226-7168

\title{
D P S Chandrakumara
}

Department of Economics, University of Sri Jayewardenepura, Sri Lanka

Email: chandra@sjp.ac.lk 


\section{INTRODUCTION}

Gender equality in education means that males and females have equal rights and access to enrolment, participation, learning, and education output. This concept is associated with the Dakar education goals (UNESCO, 2000) and the second and third in Millennium Development Goals (MDGs) of the United Nations agreed upon by the world leaders in 2000 to combat poverty, hunger, disease, illiteracy, environmental degradation, and discrimination against women (UNDP, 2010).

The second goal was to achieve universal education, while the third goal was to promote gender equality and empower women. Since education is the prerequisite for many human prospects, both males and females should have equal access to education. Formal education transforms human beings into valuable human capital, and all other capacitybuilding activities such as technical or vocational training and non-formal training play a crucial role in that process. The human capital that increases labour productivity improves people's living standards (Chandrakumara, 2012a, 2012b; Aakvik, Salvanes and Vaage, 2005; Schultz, 1961). Moreover, the developing countries' strategy is knowledge-based development, which can be achieved through the proper provision of education and training. When half of the labour force consists of females, equal access to education and training is essential when considering the country's future development.

As the honourable Minister of Education, C.W.W. Kannangara introduced the free education Act in 1944. It was later connected with a few other forces like introducing the mother tongue as the medium of instruction, the compulsory education policy, and establishing schools throughout the country (Chandrakumara, 2014). In response to these changes, the people in Sri Lanka wholeheartedly embraced free education and devoted children's time and further expenses, expecting future advantages for their families. Due to these policies, the children of peasant families in Sri Lanka have been largely transformed into valuable human capital for more than 75 years. Therefore, it is important to study how human capital formation is connected to and affect females in Sri Lanka visà-vis males.

Several pieces of literature analyse the different aspects of gender inequality in education in Sri Lanka. For example, the gender-gap characteristics identified by Athurupana, Shojo, and Ebenezer (2018) in the context of Sri Lanka covered a vast area of gender inequality. Another study articulated male and female participation in education with age groups and various provinces in Sri Lanka (Chandrakumara, 2012c). In addition, gender equality and inequality studies were conducted on access and outcome (Gunawardena, 2003), quantitative and qualitative dimensions in higher education (Gunawardena et al., 2006), education for resiliency in post-war Sri Lanka (Levi, 2018) and some similar or related issues. However, the coverage of most of these studies' analyses of gender inequality is limited up to the bachelor's degree level, and no post-graduate studies have been included. 
Furthermore, vocational training and non-formal education-related gender inequalities also have not been analysed. Besides, the issues analysed in those studies up to the bachelor's degree level should also be updated with the latest data. Therefore, this study explored gender inequality on access to education in Sri Lanka, covering formal education from Grade 1 to post-graduate level and vocational and non-formal training using the latest possible data.

Sri Lanka has been committed to providing free education for all children from grade one to the university bachelor's degree level since the mid-1940s. Although education is free for males and females alike, gender gaps can trigger due to the socio-economic-cultural background where children are living. Hence, the main objective of this paper was to analyse the current situation of gender equality in education covering formal education up to the post-graduate level and vocational and non-formal training. After implementing many activities related to free education for an extended period and pursuing the MDGs for more than two decades (UNDP, 2010), such an analysis is essential to understand where the country stands, to carry out decision making and devise necessary policy interventions for the future. The study's specific objectives were to determine gender equality/inequality features in general, examine education participation associated with gender, and distinguish female education output from males.

\section{LITERATURE REVIEW}

Although the theoretical literature in support of education at present is centred on the human capital theory introduced by Schults (1961), the pioneering economist, Smith, had written in the 'Wealth of Nations' that the skills acquired through education are a form of fixed capital that has earning power. He considered 'acquired and useful abilities of men including education embedded in men' as fixed capital. According to him, the provision of education at a low price has the possibility to reduce inequality in society. Further, he assumed that education might reduce the problems in any society due to the low literacy rate (Smith, 1776). Among the other classical economists, Malthus, Mill, and Senior also advocated on behalf of education. Malthus (1964) pointed out that education would increase the foresight of people, which would lead to the economic growth of a country. Literature argued that education would tend to support population growth, which is one of the crucial factors in economic growth (Higgins, 1968). They especially highlighted the importance of universal elementary education and equal access to education for women. Hence, it is evident that there was a consensus among the economists that education is an essential factor that generates multiple benefits for society. Among the Neo-classical economists, Marshall (1890) quoted in 'Principles of Economics' that 'the most valuable of all capital is that invested in human beings' (p.564).

Overcoming all the opinions on education, Schultz (1961) revolutionized the human capital by introducing his 'human capital theory' where he assigned education a miracle role in economic development. He pointed out that investment in education leads to the 
formation of human capital. Education and training impart skills and productive knowledge and transforms human beings into more valuable human capital. This way, according to the human capital theory, earnings rise with the increase in education level. Therefore, if women's education is lower than men's, there is an inequality in the productivity of labour and then in income too, based on gender.

The stream of ideas introduced and brought forward by the early economists has been used in later concepts with some value additions. For example, the endogenous growth model introduced in the 1980s as an alternative to Neoclassical Growth Theory also considered that growth is dependent on the accumulation of physical capital and human capital generated through education. Likewise, the views on a knowledge-based economy, high technology, innovations and inventions, and gender equality have been merged with the human capital concept at the world scale. The most popular concept is that the knowledge-based economy or development means a greater dependence on education, information, and human skills for economic growth.

Gender equality means that females should be represented equally as males in education, while gender parity in education stands for access to and participation in education (Subramanium, 2005). Some authors have attempted to articulate the human capital theory and gender concepts with the capability expansion approach of Sen (1993). The capability expansion approach can be used in the formulation of policies for an expected social change. For example, Walker (2007), Hart, Sarangapani, and Lowe (2012) rationalize applying the capability approach in education by selecting a list of education capabilities emphasizing gender equality. Therefore, it is clear that the available theories can be arranged as the theoretical framework of gender equality studies.

There is a large body of empirical literature developed based on these theories or just as empirical investigations. However, a conspicuous feature of these studies is that conclusions depend on the country or social setting of the area where the investigation was carried out. The most common view on the education of developing countries, i.e., the female education remains low compared to boys, has been studied by some researchers. A study in Pakistan attempted to explain whether the gender-based labour market rewards for the educated labour cause females to have lower education than boys (Aslam, 2009). If girls' rewards for education are smaller than for boys, the scarce resources would inequitably be allocated within the household. However, the study proved that although there was a sizable gender asymmetry in the returns, females had a significantly higher incentive to allocate more resources for their education. Therefore, the low education of girls is not necessarily due to the low demand for educated women labour in the labour market. However, the higher rewards for educated women's labour, which Aslam (2009) has found, can result from the low supply of educated women labour. Ample evidence shows that gender gaps make a significant impact on the economic growth of countries. A cross-country study conducted by Klasen and Lamanna (2009) 
revealed that gender gaps in education and employment also considerably reduce economic growth. Another study-conducted by Minasyan, et al. (2018) found out that the contribution of female education to economic growth is more extensive than that of males. Furthermore, they found out a positive relationship between gender inequality in education and growth based on 17 studies. This means that the gender gap is an indicator of economic growth, and the gap narrows with the development of a country. This can be expected since the socio-economic-cultural scenario of countries changes in the long run with the development. As a result, the male-female gap in education disappears. A similar suggestion has been made by Reimers (2020), and he stresses that men's length of schooling is higher than that of women in low-income countries. Heath and Jayachandran (2017) also affirmed that with the economic growth of developing countries, women's length of education increases faster than that of men relatively. Therefore, evidence suggests a relationship between economic growth and the gender gaps in education.

However, some complicated gender-gap behaviours are met in the literature on education. Francesconi and Parey (2018), studying the data of university graduates in Germany, assessed gender gaps related to education. They found out that men and women enter college in approximately equal numbers though more women than men can complete their degrees. Furthermore, women's high school grades were slightly better at entering college but slightly lower when they left college. This situation suggests that gender gaps are existent in education in developed countries. Osorio, et al. (2020) studied gender behaviour with STEM education (Science, Technology, English, and Maths subjects). They mention that the low participation of women in STEM education has been an issue in the societies they had observed. Investigating gender equality in nine Latin American universities on the access and graduation of females revealed gender gaps in all the indicators they used. Therefore, these findings showed the need for policies and strategies to mitigate the gender gaps at different levels. Through her cross-country studies, Lundberg (2020) showed two consistent gender gaps in education, underachievement by boys' and girls' low participation rates in STEM studies. This study suggests that the concern on gender identity may influence the educational prospects of both boys and girls through the norms of masculinity that negatively affect educational achievement.

The evidence above shows a gender gap in the students' choice for the field of study. Same as boys have a propensity to choose mathematics, technology, and engineeringrelated fields, girls are attracted to the vast area of bioscience and the specific area of medical sciences. According to Mohsin and Syed (2018), the percentage of female students in medical schools in Pakistan is so high that it is between 80 to 85 . Batyra (2017) also studied the data of the international student assessment in Turkey in 2015. She discovered that gender gaps in student achievement were consistent with the global patterns, and girls were better than boys in Turkey in reading. However, they fall behind in mathematics and science. Further, Anaya, Stafford and Zamarro (2017), also based on a study in the USA, revealed that three factors, math achievement, perceived math ability, 
and parental occupation in a science-related field, had a significant association for children to have a probability of majoring in science in college. The more interesting finding is that the estimated effects of higher math achievement levels had been nearly double for boys compared to girls. These findings show that while some societal factors like occupation or income level have an association for children to choose the science field, within the vast area of science, girls also prefer the bioscience and the medical fields in contrast to boys' interest fields of mathematics, engineering, and technology.

Investigations are available on how enhancing educational facilities of countries affected the gender gaps in education. For example, Luo and Chen (2018) studied the effect of increasing the availability of education for women on gender gaps in educational attainment in Taiwan during 1992-2012. Here, they found out that education expansion, both in compulsory and higher education, enhanced more educational opportunities for women, significantly causing a reduction in the gender gap in education in the younger groups.

However, in some societies, gender gaps are minimal in education, and therefore it is worth studying such cases to know whether the other countries can learn from these. IEA (2020) unveils evidence suggesting that gender equity in science education has already been achieved in several countries. As such, it should learn from those countries on how they wiped out gender gaps in education. Again, this conclusion directs us to consider policy solutions to minimize gender gaps in our societies.

The gender gap in access to education in Sri Lanka has also been investigated by Athurupane, Shojo, and Ebenezer (2018), covering most of the issues based on secondary data and, to a certain extent, primary data. They disclosed that some upper-middle-income and high-income countries are experiencing gender inequalities in educational participation and performance. Furthermore, scholars emphasized the low female participation in the streams, physical sciences, engineering, and technology. They revealed that although male students are underperformed in education, they get more advantages than females in the labour market. Moreover, they pointed out that the unemployment rate of educated females increases with the education level and is very high compared to males. The findings of another study proved that the female participation rate in education in certain age groups is higher than males in some provinces, while vice versa in other Sri Lanka provinces (Chandrakumara, 2012c).

As has been uncovered by the literature review, the theory shows that labour productivity depends on the education and skills, or human capital embedded in individuals. However, gender gaps exist in various ways in different countries based on the social setting of each country. Since this creates many other issues in society and the economy, policy intervention is essential for minimizing these gender inequality tendencies. Therefore, the literature review highlights the need for an in-depth investigation to understand the gender equality situation of Sri Lanka in education. 


\section{METHODOLOGY}

This paper is based on secondary data obtained from recognized institutional sources in Sri Lanka. The Department of Census and Statistics, Central Bank of Sri Lanka, Ministry of Education, University Grants Commission, and Department of Examination are the main institutional sources. The official records and surveys conducted by these institutions and the data provided in the websites were obtained and used as required to trace out the gender gaps in education.

The gender gaps in education were identified based on the following criteria:

- Literacy rates by gender

- Student enrolments in schools by gender

- Students enrolled in different grades (levels) in schools by gender

- Qualifying rates at national level examinations by gender

- The gender difference in student enrolments in government schools in different provinces

- University admissions in different study programmes or streams by gender

- Distribution of post-graduate outputs by gender

- Gender-wise student outputs of vocational and technical training institutions

- Gender-wise participation in non-formal education programmes

Table 1 shows that different variables represent the three main dimensions of gender equality/inequality.

Table 1: Gender Dimension and Variables

\begin{tabular}{ll} 
Gender Dimension & Variables Used \\
\hline General (output) differences & $\begin{array}{l}\text { Literacy rate, computer literacy, digital literacy, rate of using } \\
\text { devices to connect computers/mobile phones/smartphones }\end{array}$ \\
\hline Education participation & $\begin{array}{l}\text { School admissions in Grade 1, National school admissions in } \\
\text { Grade 1, students in schools, students in national schools, } \\
\text { enrolment in different grades, University admissions in different } \\
\text { study programmes }\end{array}$ \\
\hline Education output & $\begin{array}{l}\text { The qualifying rate at Grade 5 Scholarship Examination, O-level } \\
\text { qualified for GCE (A/L) Examination, A-level eligible to enter } \\
\text { university, Post-graduate output from the university system, } \\
\text { Outputs of Vocational and Technical Training Institutions }\end{array}$ \\
\hline
\end{tabular}

The first row of the table shows the general differences between males and females. The second row indicates the participation differences in education and training, while the third row of the table shows the gender equality/inequality variables under education output. 
The numerical data obtained from diverse institutional sources were further analysed using appropriate descriptive statistical measures. The gender gaps were identified with a high accuracy using descriptive statistics under each of the above criteria. The gender equality/inequality was analysed in terms of male-female differences in the indicative variables, and numerical, graphical, and tabulated presentations were taken as the output. However, it should be stated here that secondary data's availability constrained the analysis of gender gaps in education. Therefore, it was impossible to cover all forms of gender gaps, which could exist in education in Sri Lanka.

\section{RESULTS AND DISCUSSION}

Results are presented under each indicator of the criteria, and some indicators have subindicators as well. In addition to the values of male and female students, gender gaps in education indicators are also presented. Table 2 shows literacy rate, computer literacy rate, digital literacy rate, and a few other indicators which can be used for identifying the ability to use devices to connect computers, smartphones, tablet computers, and mobile phones. It reveals that the literacy rate is high for females, although all other indicators are low for both genders. The unique feature shown as per Table 2 is that although malefemale disparity is noticeable, in general, the literacy rate is not much conspicuous and there is a substantial gap in terms of digital literacy and the device usage.

Table 2: Literacy Rate and Computer and Digital Literacy Rates

\begin{tabular}{lrrr}
\hline Literacy Indicator & Male & Female\% & Gap (F-M) \\
\hline Literacy rate (2018) & 93.4 & 91.6 & -1.8 \\
Computer literacy (2019) & 32.9 & 28.9 & -4.0 \\
Digital literacy (2019) & 49.7 & 42.6 & -7.1 \\
Device used to connect desktop/laptop (2019) & 13.3 & 10.7 & -2.6 \\
Device used to connect smartphone (2019) & 39.2 & 33.0 & -6.0 \\
Device used to connect tablet computer (2019) & 1.1 & 0.9 & -0.2 \\
Device used to connect mobile phone (2019) & 0.9 & 0.7 & -0.2 \\
\hline
\end{tabular}

Sources: Central Bank of Sri Lanka, 2020, Department of Census and Statistics (2020).

Government schools of the country account for about 95 percent of the total student population, starting from grade 1 to grade 13 (CBSL, 2021). Figure 1 shows that at the point of grade 1 admissions, there is no significant difference between males and females when considering the all-island situation (Ministry of Education, 2020). However, in national schools, which is recognized as the best resource in the education system in the country, females' admissions in grade 1 fall behind males by nearly seven percent. Female students in national schools in all grades also lag behind males by a little more than four percent. 
Figure 1: Male and Female Students Enrolment in Schools and Gender Gap 2019

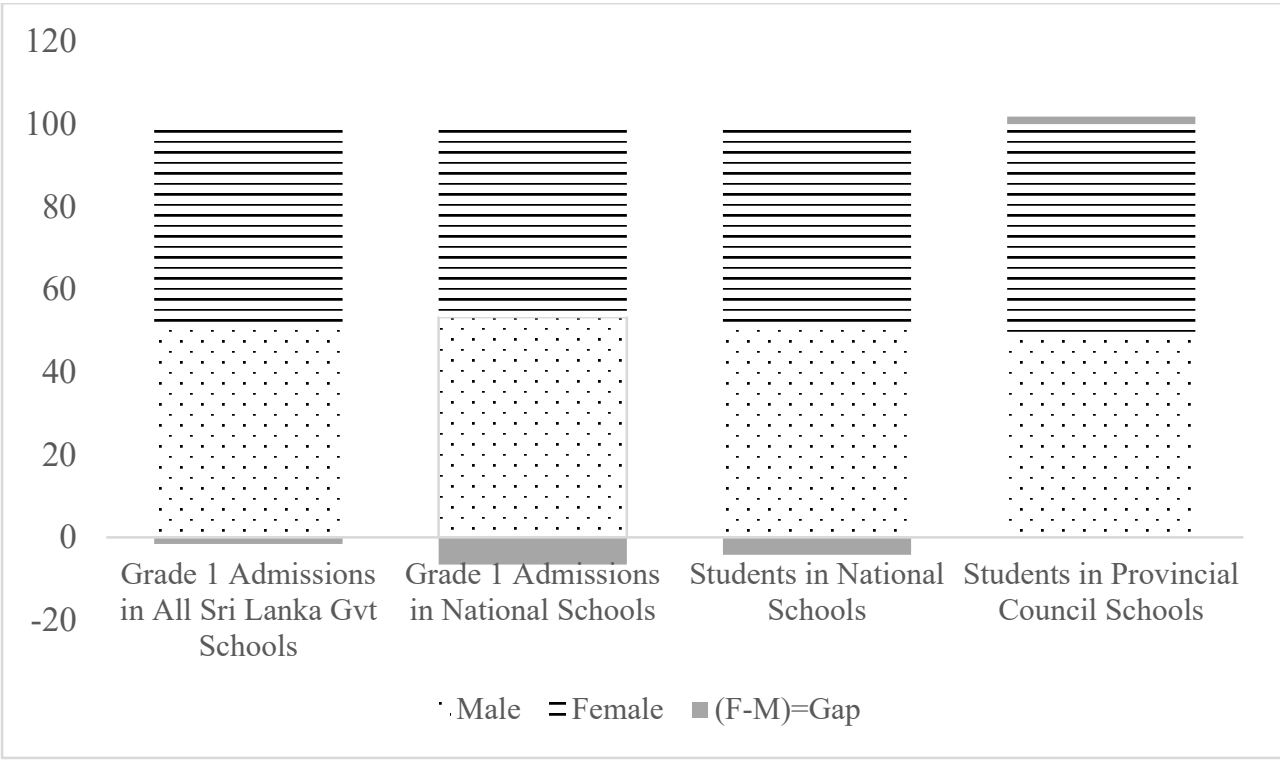

Source: Based on Ministry of Education (2020)

Figure 2 indicates how the students are registered in different grades in the island-wide government schools (Ministry of Education, 2020).

Figure 2: Male and Female Students Enrolment in Different Grades and Gender Gap 2019

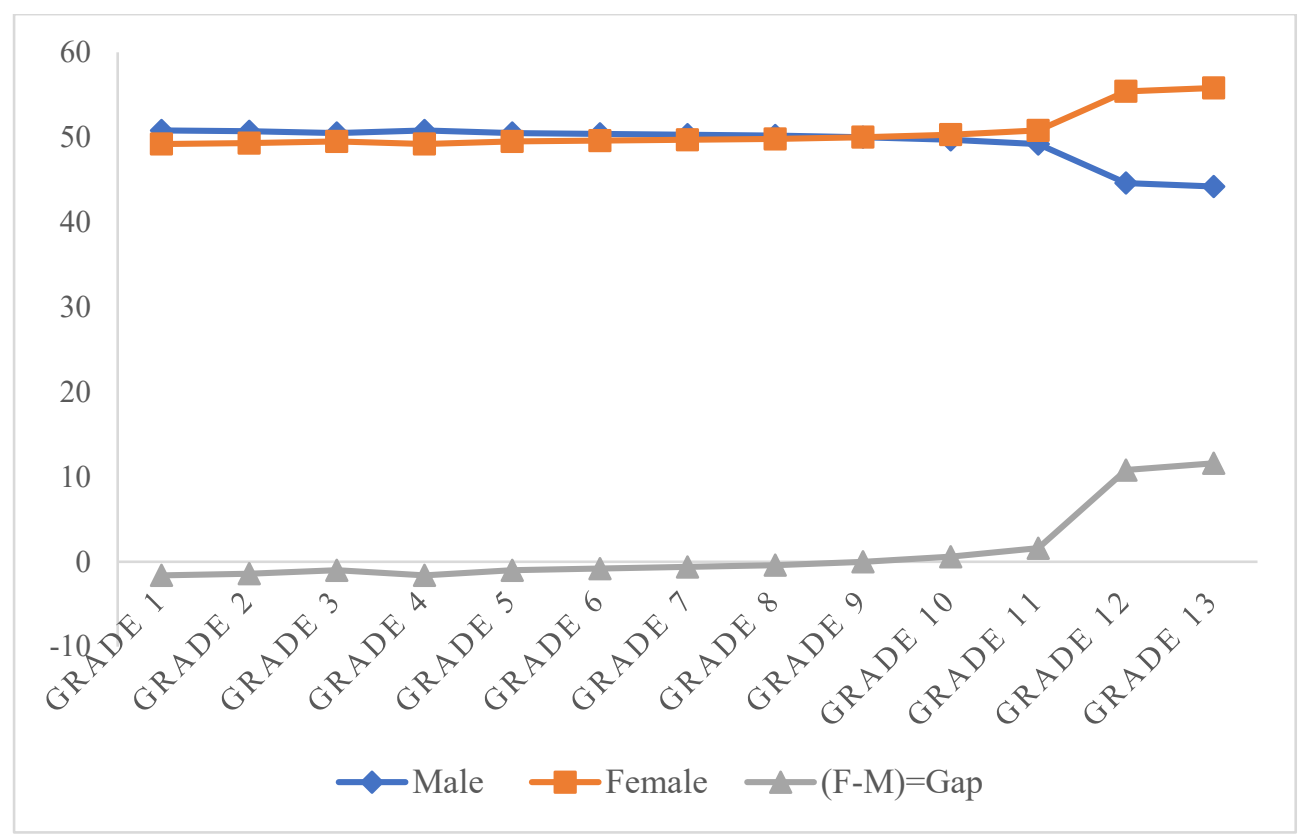

Source: Based on Ministry of Education of Sri Lanka (2020) 
It is interesting to consider that there is no significant difference between male and female student enrolments from grade 1 to grade 10 . However, females are in the lead by approximately 10 to 12 percentage points from grade 12 to 13 . This implies that a significant percentage of male students drop out of schooling after their $\mathrm{O} /$ Level examinations.

There are three nationally important examinations in the country. First is the grade 5 scholarship examination conducted covering every corner of the country. This examination is especially important for the poor and less privileged children living in rural or remote areas since they can transfer to national schools based on their marks. Moreover, there is no other justifiable way for these students to get assigned to national schools without this examination.

Table 3 shows that above the cut-off marks for female students are slightly ahead of that of male students. Second is the G.C.E. Ordinary Level Examination that determines the students' future path beyond that level. As shown in the table, female students are ahead by 16 percentage points than their male counterparts in their eligibility to register for the G.C.E. Advanced Level. The third is the G.C.E. (A/L) Examination that determines the students' continuation of studies into higher education. Table 3 again shows that female students take the lead by 16.2 in their admissibility to an institution in the university system in Sri Lanka.

Table 3: Gender Difference in Qualifying National Level Examinations

\begin{tabular}{lccr}
\hline Examination & Male \% & Female\% & Gap (F-M) \\
\hline Grade 5 Scholarship above cut-off - 2018 & 10.1 & 10.6 & -0.5 \\
O-level qualified for GCE (A/L) from no. sat - 2017 & 63.0 & 79.0 & -16.0 \\
A-level eligible to enter UTY from no. sat - 2017 & 54.9 & 71.1 & -16.2 \\
\hline
\end{tabular}

Source: Department of Examination, $(2017 ; 2018)$

The island averages of gender-wise distribution of access to education would not unveil the actual situation people are experiencing in different areas of the country. Hence, it is essential to examine the regional status of gender-wise distribution of access to education based on provinces or districts.

Table 4 shows how the male and female students are distributed in the nine provinces in Sri Lanka. Even if the difference between males and females is not significant, it shows that females in schools are slightly higher than males. This may occur for two main reasons; the first is the higher population of the female population, while the second is the low registration or the higher dropout rate of male students. Significantly, the latter can be expected from the Uva Province, where the males in schools are lower than females compared to other provinces. 
Table 4: Students in Government Schools by Province and Gender 2019

\begin{tabular}{lrrr}
\hline Province & Male\% & Female\% & Gap (F-M) \\
\hline Western Province & 49.7 & 50.3 & 0.6 \\
Central Province & 49.5 & 50.5 & 1.0 \\
Southern Province & 50.1 & 49.9 & -0.2 \\
Northern Province & 49.6 & 50.4 & 0.8 \\
Eastern Province & 50.1 & 49.9 & -0.2 \\
North-western Province & 50.0 & 50.0 & 0.0 \\
North Central Province & 49.5 & 50.5 & 1.0 \\
Uva & 49.0 & 51.0 & 2.0 \\
Sabaragamuwa & 49.5 & 50.5 & 1.0 \\
\hline
\end{tabular}

Source: Constructed based on Ministry of Education (2020)

Access to education in National schools is the scarcest opportunity in the country. The male-female gap of the student population of those schools in various provinces can also be an appropriate indicator of the gap analysis. Figure 3 reveals that in the North Central province where agriculture is the dominant livelihood male students in schools are lower than female students by 17.4 percentage points (Ministry of Education, 2020). In contrast, male students are higher in the Western Province and Eastern Provinces. The male-female difference in the number of students in National schools of many provinces is not much significant.

\section{Figure 3: Students in National Schools by Province and Gender 2019}

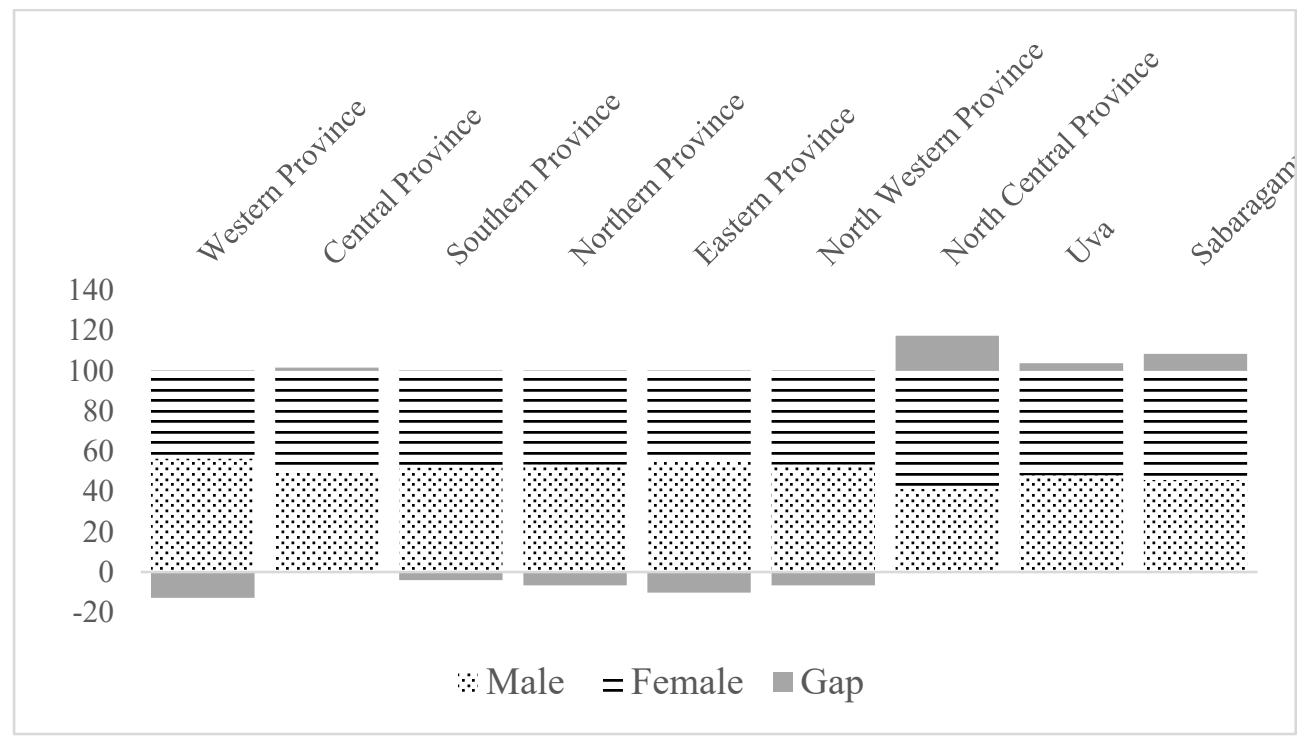

Source: Constructed based on Ministry of Education (2020) 
Although the gap between male and female students in schools was not an outstanding feature, the gap is remarkable in university admissions. Figure 4 shows university admissions by gender and the stream of study for 2018/2019 (University Grants Commission, 2020). It reveals that there is a gender gap related to every stream of study in university admissions. However, since the gap varies between streams, careful analysis of how the male and female admissions have been distributed between streams would necessarily lead to tracing useful relationships. Female registrations are the highest for the two streams, Law and Arts. Furthermore, female registrations are higher than males for Indigenous Medicine, Allied Health Sciences, Agriculture, Dental Surgery, Veterinary Science, Medicine, Commerce, and Management. However, females are remarkably behind males in their admissions to the two streams, Engineering and Technology. It also shows that females tend to concentrate in Bio-science related streams such as Indigenous Medicine, Allied Health Sciences, Agriculture, Dental Surgery, Veterinary Science, and Medicine.

\section{Figure 4: University Admissions by Stream and Gender 2018/2019}

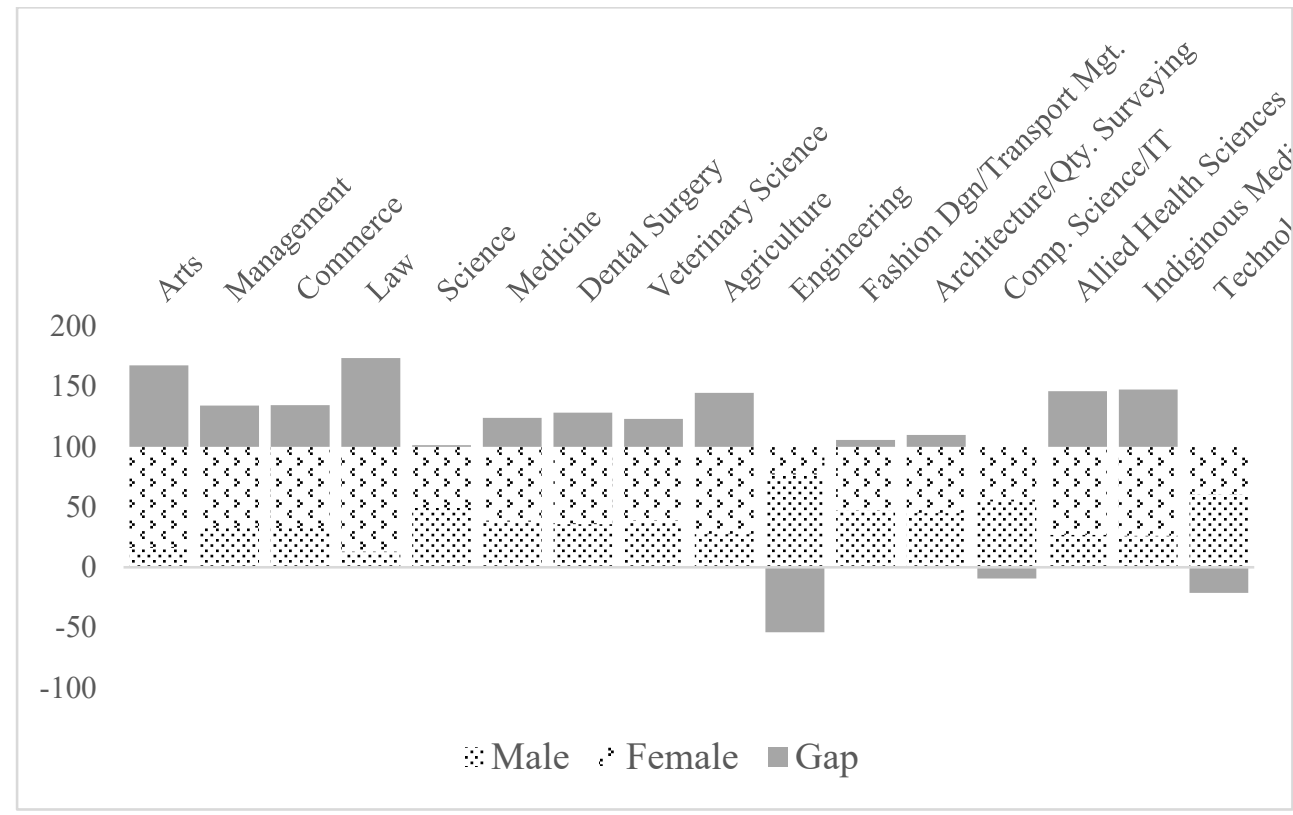

Source: Constructed based on University Grants Commission, 2020

Generally, free education opportunities in Sri Lanka end up after the bachelor's, including the honours degree, and thereafter, students have to pay out of pocket if they enrol in postgraduate academic programmes. However, there is still a shortage of systematic fulltime postgraduate programmes conducted by the public sector universities. Moreover, most of the available full-time programmes are also conducted on weekends. Nevertheless, it is important to understand how far females continue their higher studies even after their bachelor's degrees. 
Since the bachelor's degree output is almost equivalent to university admissions, the degree output can be represented by the university admissions itself. However, the situation of post-graduate education is diverse against that of the bachelors. Figure 5 shows how the post-graduate output has been dispersed between males and females related to the different fields of study or streams. It reveals that females are remarkably higher in Education, Agriculture, Arts, and Law streams while males are higher in Engineering, Indigenous Medicine, Veterinary Science, Management, and Commerce. Especially, it also shows that at the post-graduate level, engineering is less attractive among females.

\section{Figure 5: Postgraduate Output and Gender Gap 2019}

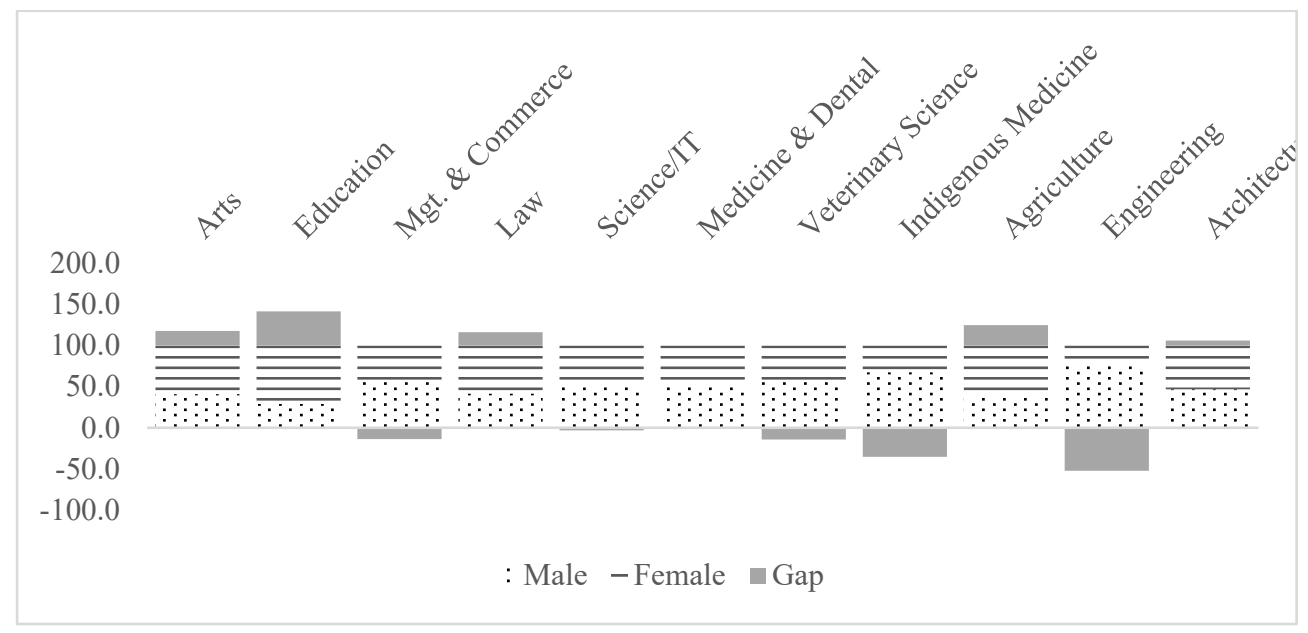

Note: Including data of Open University of Sri Lanka.

Source: Constructed based on University Grants Commission, 2020.

After the G.C.E. O/L and A/L Examinations, if their results are insufficient to enrol in a study programme in the higher education system, many students follow vocational and technical training courses. Figure 6 shows how male and female students graduated from these institutions having earning certificates of various National Vocational Qualifications (NVQ) levels (Department of Census and Statistics, 2020). The Tertiary and Vocational Education Commission (TVEC) is the regulatory body for these courses, and all vocational training centres are to be registered with the TVEC. In Sri Lanka, courses are offered at different NVQ levels, and level 4 is equivalent to higher education certificate qualification (G.C.E. A/L), while level 5 is equal to a diploma. NVQ Level 6 is equivalent to a higher diploma, while level 7 is equivalent to the degree level. Moreover, graduates passing out with these qualifications have more practical-oriented skills to work in the professions where their qualifications are matched directly. Figure 6 shows that, apart from NVQ Levels 2 and 6, the male output is higher than females in all other levels. However, enrolling both male and female students in these courses is still low. 
Figure 6: Students Output of Vocational and Technical Training Institutions by NVQ Levels and Gender 2017

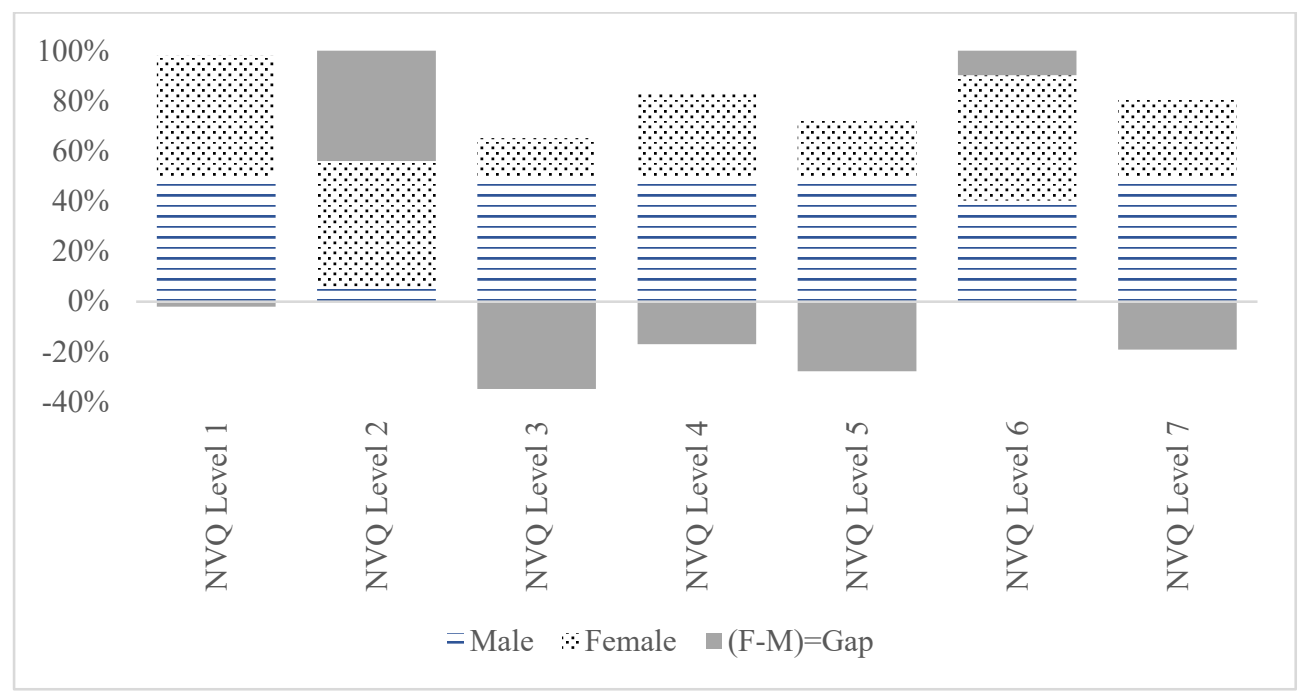

Source: Based on Department of Census and Statistics (2020)

In addition to formal education, non-formal education is also crucial for communicating and educating people on many purposes. The Ministry of Education (2020) reveals how gender-wise participation takes place in different non-formal programmes. For example, the participation of females in literacy programmes is about 42 percent and relatively lower than males, even if it does not show that it is due to their higher literacy or other reasons. However, it shows that the participation of females in community learning centres is very high compared to males, and it is about 86 percent. This means that females are more enthusiastic in community-based programmes than males.

\section{Discussion}

The paper analysed the gender inequalities in education with updated data. It explored the postgraduate, technical, vocational, and non-formal education sectors, which have not been adequately investigated for gender gaps in education in Sri Lanka. At the outset, it should be highlighted that the study achieved the main and specific objectives using reliable data despite some data limitations.

As most of the analytical sections unveil, it seems that gender gaps, which could be seen from previous studies, are still being continued. When considering the first specific objective, identifying the gender gaps in general features, it seems that the male-female difference in the general literacy rate is not significant. It proves that education has not been problematic in the provision of basics in education needed for the people with no big gender inequality. However, the gaps in using devices show that females are significantly behind males. This implies that there is a deficiency in females' technical awareness and skills compared to males though it should be improved commonly for all. 
The second specific objective, which was to examine the education participation associated with gender, has also been achieved; it shows that although there is no significant difference between males and females concerning enrolments and achievement in early grades, the differences have gradually developed in favour of females with the maturity/development/progress of children's schooling to higher grades and in university admissions. The continuation of studies by female students and their participation in education is conspicuous compared to male students. This result highlight that male students leave education than females do, due to some reasons. This may happen because generally males have more freedom and opportunities other than engaging in education due to socio-cultural reasons. Furthermore, the same socio-cultural background can compel the female children to stay in education without looking for other opportunities.

As mentioned earlier, the male-female gap in school enrolment especially starts with the G.C.E. O/L Examination favouring females. The situation that the majority are female students enrolling in G.C.E. Advanced Level can arise due to the drop out of more male students from the formal schooling system for employment purposes, enrolling in private or foreign-affiliated education programmes, and technical and vocational training institutions, etc. However, male students' departure from formal education is a matter to be further explored. It does not mean that leaving the formal system is always an adverse trend, and everyone should continue the formal education. All students do not necessarily continue education in the academic fields. Those interested in vocational and technical training should be appropriately encouraged to convert their path to technology-based aiming for a human capital-oriented development like in Taiwan, Singapore, China, etc.

Another important finding is that female admissions in National Schools are lower than that of males, by nearly 7 percent. This is a matter to be taken into account by the education policymakers to raise equality because National school admission is the scarcest opportunity a child can gain in their education life in Sri Lanka. Therefore, this right deserves to be protected.

Females are the majority when considering the eligibility to enter a public sector university in the country. However, the study could not explain why female enrolments have been concentrated in bio-science-oriented study programmes such as Allied Health, Medicine, Indigenous Medicine, Agriculture, and Dental Surgery. It needs a micro-level study to find reasons behind this. It has been found out that female students tend to deviate from engineering and technology-based education. However, so far it has not been proved; thus, it needs a micro-level qualitative study to detect the real reasons. In addition, females are dominant in the study fields of Arts, Education, Law, Commerce, and Management Studies. It should be further examined whether this trend of stream-wise supply pattern of the educated labour force would match the demand side of the labour market. Significantly, the increase in the supply of educated labour from some streams such as Arts, Education, Law, may further increase graduates' unemployment. As has 
been revealed by previous studies, the labour market demand for educated labour of some streams is male biased despite the higher academic records of females. However, as previous studies in the literature review had suggested, when there is a deficiency in the labour market supply of females in Engineering and Technology fields, a higher wage for females than males can be expected. This scenario shows the need for policy interference to manage these adverse trends based on gender imbalances in education.

The male and female output of the courses of the registered institutions in the Technical and Vocational Education and Training (TVET) sector seems to conduct more skilloriented courses. However, out of the seven levels, the female output is higher than males only in Level 2 and Level 3, and the other five are male-biased. Since female students tend to continue education despite their marginal results at $\mathrm{O} / \mathrm{L}$ and $\mathrm{A} / \mathrm{L}$, it is appropriate to introduce skill-oriented courses and encourage them to follow those courses to match the labour market requirement.

The analysis has also served the third specific objective, distinguishing female education output from males. Even if there is no substantial difference between males and females at the Grade 5 Scholarship Examination, it reveals that females show a significant lead in the output of the other two examinations. Thus, it again proves that females have progressed/ have come forward in advanced classes.

Since the bachelor's degree output is equivalent to the university admissions, there is no large gap between the admissions and output of the undergraduate study programmes. The objective of conducting examinations is to screen and filter the performance of students based on how far they have reached the required or expected level of education. This objective is achieved by assessing, ranking, determining, and offering classes to students based on their academic performance during the study programme. This method of lining up graduates based on their academic performance is crucial when they enter the labour market since employers can quickly identify the graduates by looking at/ through their rank or class or the GPA value offered by the academic institutions from which they graduated.

In contrast to the bachelor's degree, there is a large gap between the number of admissions and the number passing out completing their degrees in post-graduate programmes, though data is not properly available to prove this. However, it again shows a gap between males and females in their enrolments in various degree programmes. This situation can be expected since they have to continue in the same field of study they did in their undergraduate programmes.

The country's TVET system offers more skill-oriented courses for males and females. However, out of the seven levels, the female output is higher than males only in Level 2, Level 3, and the other five are male-biased. Since female students tend to continue education, although their $\mathrm{O} / \mathrm{L}$ and $\mathrm{A} / \mathrm{L}$ results are marginal, it is appropriate to introduce skill-oriented courses and encourage them to follow those courses to match the labour 
market requirement. However, the students whose $\mathrm{A} / \mathrm{L}$ marks are insufficient to get placement in a full-time university degree programme, become underemployed or unemployed. As a result, some look for academic courses such as external degree programmes (Kaye, 2002). Therefore, the enrolment in technical and vocational courses is low, and the government still has not developed the proper background to attract the students.

Non-formal education is the other sector that was analysed for gender gaps in training. It was proved that female participation in community learning centres has been very high compared to the males. This implies that females are more trainable at the non-formal level also than males. This is a positive indicator that shows the possibility of matching the female labour force with the labour market requirement.

\section{CONCLUSION}

The study's conclusions can be presented in terms of the three main gender dimensions, general features, education participation, and education output. Among the basic indicators which were considered to represent the general features, literacy rate does not show a significant difference between males and females. However, there is a gender gap in females' technical awareness and skills compared to males though this is low for all.

As far as education participation is concerned, there is no significant difference between males and females concerning enrolments and achievement at the primary level. However, the inequalities have gradually developed in secondary education onwards, including university admissions. There is a tendency for females to stay in education longer, whereas males drop out from education early. A crucial disparity exists in the male-female admissions in National Schools, whereas female admissions are significantly lower than males. Due to this reason, female students in all grades in National schools have become less than male students. Education output comes under the third gender equality dimension and does not show a significant difference between males and females at the Grade 5 Scholarship Examination. However, females lead in the other two examinations, G.C.E. (O/L) and G.C.E. (A/L), proving that females come forward in advanced classes and examinations. Females who are qualified to enter a university are higher than males. However, the female enrolments have been concentrated in bioscience-oriented study programmes and tend to deviate from engineering and technologybased education. In contrast, male enrolments have been centred on engineering and technology fields and diverge from bio-science-related fields. Therefore, a continuation of this trend would be likely to create a scarcity of qualified females in engineering and technology fields impact males with a similar issue in bio-science-related fields.

It may lead to wage differentials and unemployment issues concerning gender imbalances of the educated labour supply. The gender imbalance can also be observed in the output of Arts, Education and Agriculture fields. The male and female output of vocational 
training courses seems that most of the courses are male-biased. Since female students tend to continue education after GCE O/L and A/L Examinations even if they are not qualified to enter higher education, it is appropriate to enhance the availability of such training courses for females and commonly for all. Moreover, the offering of more technology-oriented courses would essentially link with the economic growth of the country. In post-graduate study programmes also, there is a gap between male and female output. Since the students tend to continue education in the same or related fields of their bachelor's degree, this situation can be generally expected. Finally, female participation in non-formal education in community learning centres seems satisfactory, and it shows the possibility of providing the necessary training through this method to females.

The key recommendations drawn from the findings and based on the main and specific objectives of the study are as follows. The deficiency in the technical awareness and skills of females compared to men should be eliminated. It is recommended to provide technical knowledge through formal education for the children under the education policy. In addition, educating the adults and updating their technical knowledge from time to time or regularly can be performed through non-formal education programmes. It should be identified why male students drop-out from formal education. Steps should be taken to take them into the economically active labour force by providing them technical or vocational training or other necessary arrangements if they are unenthusiastic to continue the formal education. The education policy should thoughtfully include necessary measures to properly direct the children and the youth in the technology training in addition to the traditional formal education. Gender inequality in the Grade 1 admissions in National Schools should be eliminated. Since this category of school is the scarcest resource available for the children of the country, a fair policy should be maintained to ensure gender equality in admissions. Immediate measures should be taken to increase the Grade 1 female intake in National Schools. It is recommended to take actions for growth in male admissions in bio-science related study programmes as well as female admissions in engineering and technology fields. Moreover, it can be recommended to introduce motivational strategies to increase males in bio-science-centred streams and females in engineering and technology-related streams.

\section{REFERENCES}

Aakvik, A., Salvanes, K. G. \& Vaage, K. (2005). Education Attainment and Family Background, Discussion Paper. Retrieved from http://www.blackwellsynergy.com/doi/abs/10.1111/j.1468

Anaya, L., Stafford, F. P., \& Zamarro, G. (2017). Gender Gaps in Math Performance, Perceived, Mathematical Ability and College STEM Education: The Role of Parental Occupation (EDRE Working Paper 2017-21). Fayetteville: University of Arkansas. 
Aslam, M. (2009). Education Gender Gaps in Pakistan: Is the Labor Market to Blame? Economic Development and Cultural Change, 57(4), 747-784.

https://doi.org/10.1086/598767

Athurupane, H., Shojo, M. and Ebenezer, R. (2018). Gender Dimensions of Educational Access and Achievement in Sri Lanka. Report No. 90, Discussion Paper Series.

Batyra, A. (2017). Gender Gaps in Student Achievement in Turkey: Evidence from the Programme for International Student Assessment (PISA) 2015. Aydin Dogan Foundation (ADV) and Education Reform Initiative (ERG). Retrieved from http://en.egitimreformugirisimi.org/wp-content/uploads/2017/03/PISA\%C4\%B0NG\%C4\%B0L\%C4\%B0ZCE.pdf

Central Bank of Sri Lanka (CBSL). (2021). Annual report - 2020. Colombo.

Chandrakumara, D.P.S. (2012a). Human capital formation within families: a study in the North Central Province of Sri Lanka. Sri Lanka Journal of Social Sciences. June/Dec 2010/2011, 33/34 (1\&2), 46-58.

Chandrakumara, D.P.S. (2012b). Achievements in Human Capital Formation in Sri Lanka. Sri Lanka Journal of Business Economics, Vol. 03 (01), 1-16.

Chandrakumara, D.P.S. (2012c). Regional Disparities of Human Capital Formation in Sri Lanka. Proceedings of the International Conference on Humanities and Social sciences - 2012, Colombo: University of Sri Jayewardenepura.

Chandrakumara, D.P.S. (2014). Employability of New Graduates in Sri lanka: Implications for Policy Development. Discussion Paper 195, Nagoya: Graduate School of International Development.

Department of Census and Statistics. (2020). Students' outputs of vocational and technical training institutions by NVQ level and sex 2017. Retrieved from http://www.statistics.gov.lk

Francesconi, M. and Parey, M. (2018). Early Gender Gaps Among University Graduates. European Economic Review. Retrieved from http://www.sciencedirect.com/science/article/pii/S0014292118300229

Gunawardena, C. (2003). Gender Equality in Higher Education in Sri Lanka: A Mismatch Beween Access and Outcomes. McGill Journal of Education / Revue Des Sciences De l'éducation De McGill, 38(03). Retrieved from https://mje.mcgill.ca/article/view/8705 
Gunawardena, C., Rasanayagam, Y. Leitan, T., Bulumulle, K., and Van Dort, A.A. (2006). Quantitative and qualitative dimensions of gender equity in Sri Lankan Higher Education. Women's Studies International Forum, 29. 562-57. DOI: 10.1016/j.wsif.2006.10.005.

Hart, C.S., Sarangapani, P.M. and Lowe, J. (2012). Sen's capability approach and social justice in education, edited by M. Walker and E. Unterhalter, Basingstoke, Palgrave Macmillan, British Journal of Sociology of Education, 33 (4), 607-619, DOI: 10.1080/01425692.2012.682785.

Heath, R. and Jayachandran, S. (2017). The Causes and Consequences of Increased Female Education and Labour Force Participation in Developing Countries. Working Paper 22766: http://www.nber.org/papers/w22766

Higgins, B. (1968). Economic Development: Problems, Principles and Policies, New Delhi: W. W. Norton and Company.

IEA (2020). Gender Gaps in Science are not a given. Compass Brief in Education. No. 11 November. Retrieved from https://files.eric.ed.gov/fulltext/ED610390.pdf

Kaye, A.R. (2002). The Current Situation of External Degrees in Sri Lanka. The Commonwealth Learning. Retrieved from http://oasis.col.org/bitstream/handle/11599/180/External studies SriLanka_Kaye 2002.pdf? sequence $=1 \&$ isAllowed $=y$

Klasen, S. and Lamanna, F. (2009). The Impact of Gender Inequality in Education and Employment on Economic Growth: New Evidence. Feminist Economics, 15(3), 91-132.

Levi, T. K. (2019). Incremental Transformations: Education for Resiliency in Post-War Sri Lanka. Education Sciences, 9(1), 11. Retrieved from $\underline{\text { http://dx.doi.org/10.3390/educsci9010011 }}$

Lundberg, S. (2020). Educational Gender Gaps, IZA Discussion Papers, No. 13630, Bonn: Institute of Labour Economics (IZA).

Luo, Y., and Chen, K. (2018). Education Expansion and Its Effects on Gender Gaps in Educational Attainment and Political Knowledge in Taiwan from 1992 to 2012. International Journal of Educational Development 60, 88-99.

Malthus, T.R. (1964). Principles of Political Economy, New York: Augustus M. Kelly Bookseller.

Marshall, A. (1890). Principles of Economics, London: Macmillan and Co. Limited. 
Minasyan, A., Zenker, J., Klasen, S. and Vollner, S. (2018). Educational Gender Gaps and Economic Growth: A Systematic Review and Meta-Regression Analysis. Discussion Paper No 255. Retrieved from http://hdl.handle.net/10419/181448

Ministry of Education. (2020). Annual School Census of Sri Lanka: Final Report 2019. Colombo. Retrieved from http://www.statistics.gov.lk/Education/StaticalInformation/SchoolCensus /2019

Mohsin, M., and Syed, J. (2018). The Missing Doctors- An Analysis of Educated Women and Female Domesticity in Pakistan. Retrieved from https://onlinelibrary.wiley.com/doi/abs/10.1111/gwao.12444

Osorio, C., Ojeda-Caicedo, V.V., Villa, J.L., and Contreras-Ortiz, S.H. (2020). Participation of Women in STEM Higher Education Programs in Latin America: The Issue of Inequality. 18th LACCEI International Multi-Conference for Engineering, Education, and Technology: "Engineering, Integration, and Alliances for a Sustainable Development" "Hemispheric Cooperation for Competitiveness and Prosperity on a Knowledge-Based Economy", July 27-31, 2020, Virtual Edition.

Reimers, P. (2020). Structural Change, Gender Gaps, and Educational Choice. Goethe University Frankfurt. Retrieved from http://dx.doi.org/10.2139/ssrn.3691055

Schultz, T. W. (1961). Investment in Human Capital. The American Economic Review, $1(2), 1-17$.

Sen, A. (1993). Capability and Well-being. The Quality of Life. Edited by M. Nussbaum, Sen The Quality of Life. Oxford: Clarendon Press.

Smith, A. (1776). An Inquiry into the Nature and Causes of the Wealth of Nations, with an introduction by D. D. Raphael (1991), London: David Campbell Publishers Ltd.

Subramanium, R. (2005). Gender equality in education: Definitions and measurements. International Journal of Educational Development, 25, 395-407.

UNDP. (2010). What Will It Take to Achieve the Millenium Development Goals? - An International Assessment. Retrieved from https://www.undp.org/publications/what-will-it-take-achieve-mdgs-international$\underline{\text { assessment }}$

UNESCO. (2000). The Dakar framework for action, education for all: meeting our collective commitments. Retrieved from https://sustainabledevelopment.un.org/content/documents/1681Dakar\%20Frame work $\% 20$ for $\% 20$ Action.pdf 
University Grants Commission. (2020). Sri Lanka University Statistics 2019, University Grants Commission, Sri Lanka.

Walker, M., and Unterhalter, E. (2007). Amartya Sen's Capability Approach and Social Justice in Education. Basingstoke. Retrieved from Palgrave Macmillan https://doi.org/10.1057/9780230604810 